\title{
REVOLUSI BIRU DAN HUMAN SECURITY NELAYAN DI KUSAMBA KLUNGKUNG
}

\author{
I Wayan Tagel Eddy ${ }^{1}$, Anak Agung Ayu Rai Wahyuni ${ }^{2}$ \\ Program Studi Sejarah Fakultas Ilmu Budaya Universitas Udayana
}

\begin{abstract}
Abstrak
Revolusi biru (blue revolution), sebagai strategi pembangunan dan upaya akumulasi kapital, bukan hanya tidak berhasil mengangkat nelayan dari kemiskinan yang melilit mereka, namun ia juga menyisakan persoalan bagi keberlangsungan human security nelayan. Tidak hanya gagal menangkap apa yang sebenarnya menjadi kebutuhan nelayan, paket kebijakan modernisasi perikanan seringkali malah merugikan nelayan dan masyarakat pesisir pantai. Artikel ini bertujuan untuk mengetahui proses dan bentuk modernisasi perikanan (minapolitan) yang sedang dalam proses pembangunan serta bagaimana respon para nelayan dan masyarakat pesisir terhadapnya? Selain itu, akan memeriksa apa kira-kira yang akan diakibatkan oleh modernisasi perikanan bagi keberlangsungan human security kehidupan nelayan dan masyarakat pesisir. Penulis terlebih dahulu memulai uraian dengan mengelaborasi konsep pembangunan, human security dan revolusi biru sebelum memberikan ilustrasi kasus nelayan dan masyarakat pesisir, berkaitan dengan pembangunan minapolitan, di kawasan pelabuhan Kusamba Kelungkung.
\end{abstract}

Kata Kunci: Revolusi Biru, Human Security, Masyarakat Pesisir

\section{PENDAHULUAN}

Salah satu visi yang hendak diwujudkan Presiden Joko Widodo adalah menguatkan bangsa Indonesia pada sektor maritim. Pernyataan visi ini sebenarnya bukan hal baru bagi negeri kita, tetapi karena isu ini dituangkan sebagai komitmen Presiden untuk memajukan sektor maritim pada lima tahun pemerintahan Jokowi-JK maka ia menjadi sangat strategis. Menjadi amat penting bagi seluruh pemangku kepentingan untuk fokus pada kebijakan in agar sejalan dengan kebijakan pemerintah pusat dalam memprioritaskan arah kebijakan pembangunan.

Debat mengenai pembangunan dan hak asasi manusia menjadi topik besar yang diperbincangkan oleh para analis dan perancang kebijakan di level internasional. Keduanya, ditambah demokrasi, telah menjadi perdebatan ideal politik hegemonik pada sekitar tahun 1980-an yang lalu. Bermula tahun 1986 ketika PBB mengumumkan "Declaration on the Rights to Development" yang menegaskan bahwa pembangunan adalah hak asasi manusia di seluruh dunia, berbagai forum internasional diselenggarakan seperti World Conference on Women(1995) di Beijing, World Summit for Social Development (1995) in Copenhagen dan World Conference on Human Rights (1993) di Wina yang menghasilkan "Vienna Declaration and Programme of Action".
Di dalam deklarasi Wina, artikel delapan menegaskan bahwa pembangunan, hak asasi manusia dan demokrasi saling bergantung dan saling memperkuat satu sama lain. Banyak pemikir yang meyakini pandangan ini. Meyer (2002), misalnya, menegaskan bahwa pada dasarnya, hak asasi manusia dan demokrasi adalah dua hal yang dibangun di atas ide fundamental yang sama yaitu kesetaraan dan martabat tiap individu. Keduanya saling tergantung dan saling membutuhkan satu sama lain. Hak asasi manusia menjamin tiap individu untuk berkembang secara bebas dan mendapat pengakuan terhadap nilai-nilai, keyakinan, pilihan, dan ketertarikan mereka. Pengakuan dan penegakan hak asasi manusia hanya bisa dilakukan dalam demokrasi. Sebaliknya demokrasi hanya bisa berkembang dengan baik apabila hak asasi manusia telah ditegakkan; dihormati, dilindungi dan dipenuhi.Ignatieff (2000) menjelaskan bahwa pembangunan merupakan upaya politik untuk pencapaian hak asasi manusia (human rights) dengan tujuan pemerataan bagi setiap individu yang berhak memperoleh penghidupan yang layak dan cukup berdasarkan pemenuhan kebutuhan dasarnya.

Membicarakan pembangunan tidak bisa untuk tidak memeriksa salah satu institusi yang dikaitkan dengan isu hak asasi manusia, yaitu pasar (market). Pasar merupakan institusi sosial yang didesain untuk menciptakan efisiensi ekonomi.Pertumbuhan (growth) dan efisiensi (efficiency) adalah mantra 
penting dalam sistem ekonomi pasar.Namun pasar memiliki masalah bawaan yang dibawa ke manamana yaitu, akumulasi kapital.Pasar hanya peduli terhadap efisiensi dan percepatan pertumbuhan ekonomi, tidak pada kesetaraan sosial. Pada titik ini, ia mendatangkan masalah bagi perlindungan hak-hak ekonomi dan sosial orang lain yang haknya terlanggar karena keserakahan ekonomi pasar bebas. Untuk kepentingan artikel ini, kaitan antara hak asasi manusia dan pasar digunakan.

\section{Human Security}

$\begin{array}{cccc}\text { Gagasan } & \text { tentang } & \text { human security } \\ \text { memunculkan perdebatan tentang apa itu }\end{array}$ keamanan dan bagaimana cara mencapainya. Perdebatan terjadi, lebih karena sudut pandang, pengalaman dan prioritas yang berbeda dari setiap pemerintahan nasional dalam mendefinisikan human security yang sebelumnya konsep "keamanan" hanya dipahami sebagai keamanan nasional atau negara nasional dari gangguan militer negara lain, kini konsep keamanan bergeser ke arah keamanan manusia dari hal-hal yang nonmiliter.

Artikel ini hendak menggunakan konsep human security ini di dalam proses pembangunan minapolitan di Kusamba dan implikasinya bagi nelayan dan masyarakat pesisir di sana. Sejak tahun 1994 isu human security menandai babak baru dalam hubungan internasional.Adalah Dr. Mahbub ul Hal orang yang pertama kali memberikan perhatian pada human security di dalam forum-forum UNDP. Di dalam UNDP's 1994 Human Development Report, human security didefinisikan ke dalam threats in seven areas, yaitu; pertama, economic security yang didasarkan pada kemampuan pendapatan dasar tiap individu, akses mereka terhadap pekerjaan dan jaringan kenyamanan keuangan. Di negara-negara berkembang persoalan economic security mungkin menjadi problem serius karena di negara-negara tersebut problem pengangguran menjadi faktor penting selain tegangan politik dan kekerasan etnis; kedua, food security yang mengharuskan bahwa seluruh manusia kapan pun dan di mana pun harus memiliki akses ekonomi dan fisik pada pangan. Hal yang perlu diperhatikan berkaitan dengan food security ini adalah; (1) ketersediaan pangan; (2) distribusi pangan; (3) kurangnya daya beli dan ini berkorelasi dengan economic security.

Ketiga, health security yang bertujuan untuk menjamin perlindungan minimum dari penyakit dan gaya hidup yang tidak sehat. Di negara-negara berkembang penyebab utama kematian adalah infeksi dan penyakit parasitic. Baik di negaranegara industri dan negara-negara berkembang health security menghantui orang-orang miskin di pedesaan, terutama ibu-ibu dan anak-anak. Pelayanan kesehatan, ketersedian air bersih dan kebutuhan-kebutuhan dasar yang lain menjadi sangat penting dalam menjaga health security; keempat, environmental security yang bertujuan untuk melindungi orang dari rusaknya kondisi lingkungan hidup (natural environment). Sementara di negara-negara berkembang isu tentang kurangnya akses pada sumber daya air menjadi isu penting dalam environmental threatment, di negara-negara industri maju isu pokoknya adalah pencemaran udara (air pollution). Persoalan emisi, gas rumah kaca menjadi isu-isu environmental security yang lain, yang menjadi perhatian banyak negara belakangan ini.

Kelima, personalsecurity yang bertujuan melindungi setiap orang dari kekerasan fisik, oleh negara ataupun di luar negara, dari kekerasan personal atau kelompok-kelompok di dalam negara, atau dari kejahatan atau tindakan kriminal orang-orang dewasa; keenam, community security yang bertujuan untuk melindungi setiap orang (people) dari hilangnya nilai-nilai dan hubungan-hubungan tradisional di mana mereka hidup, atau dari kekerasan etnik dan sektarianisme. Setiap orang tidak dibenarkan dicabut atau dipisahkan dari lingkungan komunitas tradisionalnya. Community security ini memasukkan indigenous people sebagai isu penting, misalnya hak-hak aboriginal; ketujuh, political security yang bertujuan untuk memuliakan hak-hak asasi manusia paling dasar, seperti aman dari sistem penyiksaan politik, tekanan politik dari pemerintah yang mengontrol ide dan informasi. Pelanggaran hak asasi manusia seperti ini sering kali dialami rakyat di negaranegara yang memberlakukan kontrol ketat terhadap warganya.

Secara ringkas UNDP mendefinisikan human security sebagai : "first, safety from such chronic threats such as hunger, disease, and repression. And, second, ...protection from sudden and hurtful disruptions in the patterns of daily life - whether in homes, in jobs or in communities". Jadi, secara umum, definisi human security menurut UNDP mencakup "freedom from fear and freedom from want". 


\section{Revolusi Biru}

Revolusi biru (blue revolution) memang tidak setenar Revolusi Hijau (green revolution). Proyek revolusi biru atau modernisasi perikanan, yang dimulai pada tahun 1970-an sebagai strategi pembangunan, dikembangkan melalui penetrasi kapital dan peralihan arus modal dan teknologi dengan tujuan meningkatkan efisiensi dan produktivitas tangkapan. Sejak saat itu kebijakan dan program modernisasi perikanan, seperti motorisasi, GERBANG MINA BAHARI (Gerakan Pembangunan Nasional Kelautan dan Perikanan), PROPEKAN (Program Peningkatan Ekspor Hasil Perikanan Budidaya) dan PEMP (Pemberdayaan Ekonomi Masyarakat Pesisir), mulai digalakkan. Fasilitas kredit usaha, mesin tangkap yang lebih modern, pembangunan infrastruktur pelabuhan perikanan, ruang pendingin (coldstorage), tempat pengeringan dan tempat pelelangan ikan (TPI) merupakan beberapa paket kebijakan modernisasi perikanan yang dilakukan pemerintah saat itu.

Kemudian, antara tahun 1980-1996, pemerintah memperbaharui kebijakan modernisasi perikanan dengan diluncurkannya kebijakan deregulasi berupa pengembangan alat tangkap, pembangunan pelabuhan, penambahan armada penangkapan, impor kapal bekas hingga pemberian izin kapal asing untuk menangkap ikan di perairan Indonesia. Pemerintah juga menerbitkan berbagai regulasi terkait dengan modernisasi perikanan, misalnya, Keppres No. 39 Tahun 1980 dan Undang-undang tentang Perikanan Tahun 1995.

Lalu pertanyaan yang mendesak dijawab apakah modernisasi perikanan (blue revolution) yang telah ditempuh sejak empat puluh tahun yang lalu memberikan dampak positif bagi kehidupan nelayan. Berbagai penelitian telah dilakukan untuk menjawab pertanyaan mendasar ini. Dan jawabannya sama bahwa peningkatan tangkapan dalam jumlah yang besar ternyata tidak seirama dengan peningkatan kesejahteraan nelayan karena; pertama, faktor kebijakan yang tidak mempertimbangkan adaptabilitas lokal; kedua, faktor-faktor sosial sebagai "ruang" di mana kebijakan modernisasi perikanan dilaksanakan tidak diperhitungkan.

Setidaknya penelitian yang dilakukan oleh Raymond Firth (1975), Iskandar dan Matsuda (1989), Salman dan Lampe (1993), Satria (2001), Arief, A.A (2002) dan Agusanty (2004) mengonfirmasi mengenai kegagalan revolusi biru mengangkat keterpurukan nelayan dari jurang kemiskinan yang melilit mereka. Kenyataan seperti ini hampir sama dialami oleh setiap daerah. Penelitian Nasikun (1996) di Muncar Jawa Timur, Elfliandri (2002) di Sumatra Barat, dan Iwan (2002) di Kabupaten Tanjung Jabung, Jambi menunjukkan bahwa penetrasi kapital dan alih teknologi yang tersemangati oleh nalar akumulasi kapital (kapitalisme) semakin menyeret nelayan ke arah ketergantungan dan kemiskinan struktural.

\section{Modernisasi Perikanan Di Kusamba}

Kusamba terkenal sebagai Pelabuhan Perikanan Pantai (PPP) di Kabupaten Klungkung. Berbagai aktivitas ekonomi yang mengandalkan sumber daya laut setiap hari berlangsung di timur pulau Bali. Seperti daerah-daerah sentra perikanan lain di Indonesia, Kusamba tidak luput dari agenda modernisasi perikanan yang kembali dicanangkan oleh pemerintah melalui program minapolitan.

Di Kusamba terdapat tempat pelelangan ikan (TPI) yang menangani distribusi hasil tangkapan ikan para nelayan. Fasilitas lainnya yang tersedia adalah Solar Packed Dealer untuk Nelayan (SPDN) atau Stasiun Pengisian Bahan Bakar Minyak Untuk Nelayan (SPBN). Dengan adanya SPDN nelayan lebih mudah untuk memperoleh BBM.Hasil tangkap ikan di Kusamba didukung oleh adanya beberapa unit pabrik pengolahan ikan.Hasilnya tidak hanya dijual di Kusamba, tetapi juga dipasarkan ke beberapa wilayah Bali lainnya, baik dalam bentuk ikan mentah maupun ikan olahan.

\section{Mode Produksi (Mode of Production) sebelum Modernisasi}

Kini, Kusamba beranjak menjadi kota ikan dan identik sebagai sentral perikanan di wilayah Klungkung dengan berbagai institusi pendukungnya. Sebelum modernisasi perikanan digalakkan oleh pemerintah Orde Baru pada tahun 1970-an, mayoritas masyarakat pesisir Kusamba masih mengandalkan pertanian sebagai sumber penghidupan utama. Hingga akhir tahun 1980-an sebagian besar dari mereka masih berprofesi sebagai petani. Meskipun begitu, mereka juga ikut melaut dan bergabung dengan nelayan yang telah lebih dulu terjun di sektor perikanan dan kelautan, yang biasanya dikuasai oleh orang-orang Bugis dan orang-orang Madura yang memiliki tradisi panjang dalam urusan melaut. Selain bertani dan melaut, mereka juga mencari "nener" (udang kecil) dibibir pantai dan nyuttu', yaitu mencari "garegu", bahan untuk membuat terasi. 


\section{Awal Modernisasi dan Respon Masyarakat Lokal}

Penetrasi kapital dan alih teknologi adalah instrumen utama modernisasi perikanan. Siap atau tidak, menguntungkan atau sebaliknya, masyarakat nelayan harus menerimanya sebagai sesuatu yang musti terjadi, karena ini adalah kehendak negara yang baru berdiri dan mengimpikan pembangunan sebagai jalan menuju kesejahteraan. Menolaknya berarti cap komunis sudah menanti di depan mata.

Kusamba juga mengalami hal serupa seperti di daerah-daerah pelabuhan perikanan yang lain. Berbagai progam modernisasi perikanan meliputi bantuan perahu, mesin, alat tangkap dan penguatan modal segera diluncurkan oleh pemerintah. Masalahnya, pelaksanaan dan manfaat bantuanbantuan ini hanya dinikmati oleh kelompokkelompok tertentu. Sangat jarang bantuan bisa dirasakan langsung oleh nelayan kecil, tapi malah yang mendapat bantuan adalah tokoh-tokoh masyarakat yang kuat secara ekonomi dan memiliki akses ke lingkungan politik dan pemerintahan.

Program bantuan yang digulirkan oleh pemerintah, dan tersedianya pabrik pengolahan dan pengalengan ikan serta menyaksikan jumlah tangkapan ikan yang sangat luar biasa ketika itu menggoda dan mendorong, tidak hanya orangorang Kusamba untuk segera menjadi nelayan, namun juga orang-orang dari luar Kusamba berdatangan untuk menjadi awak perahu yang dimiliki oleh orang Kusamba.

Kusamba sebagai penghasil ikan di wilayah Klungkung dengan hasil tangkapan yang lumayan banyak telah mendorong pemerintah untuk menjadikan Kusamba sebagai kawasan minapolitan. Pengembangan minapolitan merupakan bagian dari rencana strategis pembangunan kelautan dan perikanan.

\section{Potensi Kerentanan Human Security Nelayan \\ Pelaksanaan pembangunan minapolitan di} Kusamba mengungkap terjadinya informasi yang asimetrik (asymmetric information) karena bukan hanya sebagian besar nelayan tidak mengetahui apa itu minapolitan, apa keuntungan dan kerugian yang mungkin mereka akan hadapi kelak jika minapolitan sudah selesai dan beroperasi, akan tetapi justru terdapat penyesatan informasi yang disampaikan kepada mereka. Tokoh nelayan setempat menjelaskan bahwa pemilik perahu, nelayan dan masyarakat pesisir pantai Kusamba merasa senang atas pembangunan minapolitan karena mereka dibuatkan tempat sandar atau "tambat labuh" perahu yang luas. Dengan adanya dermaga dan tempat bersandar perahu yang luas, mereka tidak lagi perlu berhimpit-himpitan seperti sekarang.Ini yang hanya diketahui oleh nelayan. Mereka tidak tahu bahwa dermaga itu bukan untuk mereka, tapi untuk kapal-kapal besar yang akan berlabuh di pantai mereka nanti.

"Tambat Labuh" atau tempat parkir perahu ini berada dalam otoritas Dinas Kelautan dan Perikanan (DKP) Provinsi Bali. Sudah sejak lama, nelayan Kusamba memiliki cara bertahan (resilience) ketika menghadapi siklus alam yang tiap bulan datang menyapa mereka. Biasanya pada hari-hari tertentu yaitu saat terang bulan mereka tidak pergi melaut karena ikan-ikan di laut tidak terlihat oleh nelayan sehingga sulit ditangkap. Lalu apa yang dilakukan nelayan untuk memenuhi kebutuhan ekonomi keluarganya? Mereka para nelayan yang tidak melaut ini tetap bekerja dengan mencari kerang di pantai dan mereka jual kepada para pengepul kerang yang selanjutnya menjualnya di pasar.

Kepegasan hidup nelayan seperti di atas akan segera menghadapi gangguan berbarengan dengan pembangunan minapolitan karena dua alasan, yaitu; pertama, pembangunan minapolitan membutuhkan areal yang luas, artinya, dengan begitu nelayan tidak bisa lagi mencari kerang pada musim terang bulan, sebagai sumber nafkah ketika mereka tidak melaut. Hal ini disebabkan oleh tempat (pantai) di mana mereka mencari kerang sudah tidak ada untuk kepentingan area dermaga. Kedua, musim terang bulan juga dimanfaatkan oleh para nelayan untuk berkumpul bersama anak dan istri beserta sanak keluarga yang lain setelah musim-musim melaut berlalu. Pada musim ini nelayan juga melakukan anjangsana kepada sesama nelayan dan bersosialisasi dengan masyarakat atau komunitas yang lain. Kenikmatan individu dan kenyamanan sosial semacam ini berangsur akan hilang seiring melemahnya kelembagaan-kelembagaan sosial akibat himpitan ekonomi.

Gangguan lain yang potensial akan dialami oleh keluarga nelayan yang memiliki perahu kecil dengan kapasitas kecil dan melautnya tidak terlalu jauh dari pantai. Karena ongkos biaya yang harus mereka keluarkan akan lebih banyak dari pada sebelum minapolitan beroperasi. Dan kini, hal ini mulai dirasakan oleh para nelayan pemilik perahu 
kecil.Belum lagi keamanan di tengah laut lepas dengan kondisi perahu yang kurang memadai.

\section{SIMPULAN}

Pembangunan selalu memunculkan ketegangan sosial di antara para pihak yang terlibat di dalamnya atau mereka yang hanya menjadi penonton dan objek pembangunan, walau kadang bersifat latent dan tidak terungkap. Seperti kasus pembangunan minapolitan di Kusamba, misalnya, para elit lokal di sana cenderung mendiamkan sambil menelisik peluang-peluang ekonomi yang akan mereka dapatkan dari proses pembangunan minapolitan, karena mereka meyakini minapolitan akan menguntungkan bagi mereka. Sementara nelayan kecil dan masyarakat pesisir yang hanya menggantungkan hidup mereka pada laut, lambat laun termarginalisasi dan termanipulasi oleh informasi yang tidak seimbang, atau bahkan tidak ada informasi alternatif yang menjelaskan apa yang mereka akan alami setelah minapolitan menjadi kenyataan. Inilah awal terlanggarnya human security nelayan.

Pengalaman banyak negara menunjukkan bahwa hasrat pembangunan yang digerakkan oleh semangat pertumbuhan ekonomi (economic growth) dan nafsu akumulasi kapital hanya akan menyebabkan terlanggarkan hak asasi manusia (human rights) atau dalam bahasa yang lebih teknis human security. Maka dengan menyadari potensi destruktif model pembangunan seperti ini, diharapkan pembangunan tidak hanya direduksi ke dalam aspek material belaka, akan tetapi harus dipandang sebagai upaya pembebasan manusia (development as freedom) melalui the process of the enlarging the range of people's choicies.

Di tengah upaya Pemerintah Kabinet Kerja untuk menjadikan Indonesia sebagai Poros
Maritim Dunia, yakni Laut sebagai sumber kemajuan dan kesejahteraan baru bagi bangsa Indonesia, perlu diupayakan bagaimana membangun kelautan, khususnya perikanan, berbasis ekonomi biru untuk menghasilkan pertumbuhan ekonomi yang inklusif, ramah lingkungan, dan berkelanjutan bagi kemajuan dan kesejahtraan rakyat Indonesia dalam upaya mewujudkan tiga pilar kelautan dan perikanan kita, yaitu kedaulatan, keberlanjutan, dan kesejahtraan. Pemberdayaan masyarakat nelayan dan pesisir tidak semata pada ekonomi, tetapi juga penguatan posisi politik mereka melalui penjaminan hak-hak agar mampu mengartikulasikan dan mempertahankan kepentingannya dalam setiap kontestasi.Jika kita masih percaya bahwa kita ini adalah bangsa bahari, maka jaminan terhadap hakhak masyarakat nelayan dan pesisir itu merupakan suatu keniscayaan.Jalesveva Jayamahe.

\section{DAFTAR PUSTAKA}

Fukuoka, Masanobu. 2012. Revolusi Sebatang Jerami. Jakarta: Yayasan Pustaka Obor Indonesia.

Pauli, Gunter. 2013. The Blue Economy. Jakarta: Akast Publishing.

Satria, Arif. 2015. Sosiologi Masyarakat Pesisir. Bogor: Yayasan Obor Idonesia. , 2009a. Pesisir dan Laut untuk Rakyat. Bogor: IPB Press.

.2009b. Ekologi Politik Nelayan. Yogyakarta: LKIS.

2015. Politik Kelautan dan Perikanan. Jakarta: Yayasan Pustaka Obor Indonesia. 